\title{
Usulan Perbaikan Lintasan Produksi untuk Mereduksi Waste pada Departemen Kerja Produksi dengan Kombinasi Lean Manufacturing dan Theory of Constraints
}

\author{
Mangunah Istikomah ${ }^{*}$, Endang Prasetyaningsih \\ Prodi Teknik Industri, Fakultas Teknik, Universitas Islam Bandung, \\ Indonesia. \\ *mangunah.istik@gmail.com, endangpras@gmail.com
}

\begin{abstract}
CV. BJT is an industry that produces fabrics with high value. The problem faced by CV.BJT is the imbalance of production flow that results in unmet production targets, so that the throughput obtained is not maximum. The imbalance of production flow occurs because the allocated capacity is not managed and scheduled properly, which is causing Work in Process (WIP) and waiting waste. Basically, CV.BJT has set the standard of WIP which is $30 \%$ of the overall WIP. However, in fact, WIP buildup was found by 33,33\% at Stenter workstation. The causative factor is capacity constraints. Therefore, improvement efforts are needed to overcome the problems faced by CV.BJT. This research aims to reduce waste also manage and schedule constraint workstations. Improvement efforts are made by implementing a combination of Lean Manufacturing and Theory of Constraints. The improvements can reduce waiting time from 406,51 to 182,65 minutes /batch. This is due to the implementation of conWIP system that makes WIP decreased by $31,25 \%$ from the initial condition. While the constraints workstation is managed and scheduled by Drum Buffer Rope method, so that the capacity of future conditions can meet production targets. When the production target is met, the throughput increases from $\mathrm{Rp} 9.255 .067 .125$ to $\mathrm{Rp} 10.297 .640 .532$. The impact of improvement efforts can reduce production lead time from $2.229,48$ to $2.005,62$ minutes /batch.
\end{abstract}

Keywords: Lean Manufacturing, Theory of Constraints (TOC), Drum Buffer Rope (DBR), ConWIP.

\begin{abstract}
Abstrak. CV. BJT merupakan industri yang menghasilkan kain dengan value tinggi. Permasalahan yang dihadapi oleh CV.BJT yaitu ketidakseimbangan aliran produksi yang mengakibatkan target produksi tidak terpenuhi, sehingga throughput yang diperoleh tidak maksimum. Ketidakseimbangan aliran produksi terjadi karena kapasitas yang dialokasikan tidak dikelola dan dijadwalkan dengan baik, sehingga menimbulkan Work in Process (WIP) dan waiting waste. Pada dasarnya, CV.BJT sudah menetapkan standar adanya WIP yakni sebesar 30\% dari WIP keseluruhan. Namun, kenyataanya masih ditemukan penumpukan WIP sebesar 33,33\% di stasiun kerja Stenter. Faktor penyebabnya yaitu capacity constraints. Oleh karena itu, perlu adanya upaya perbaikan untuk mengatasi permasalahan yang dihadapi oleh CV.BJT. Penelitian ini bertujuan untuk mereduksi waste dan mengelola serta menjadwalkan stasiun kerja constraints. Upaya perbaikan dilakukan dengan menerapkan kombinasi Lean Manufacturing dan Theory of Constraints. Perbaikan tersebut dapat mereduksi waktu tunggu dari 406,51 menjadi 182,65 menit/batch. Hal tersebut karena adanya pemberlakuan sistem ConWIP yang membuat WIP menurun sebesar 31,25\% dari kondisi awal. Sementara stasiun kerja constraints dikelola dan dijadwalkan dengan metode Drum Buffer Rope, sehingga kapasitas kondisi future dapat memenuhi target produksi. Ketika target produksi terpenuhi, maka throughput meningkat dari Rp. 9.255.067.125 menjadi Rp. 10.297.640.532. Dampak dari upaya perbaikan dapat mereduksi production lead time dari 2.229,48 menjadi 2.005,62 menit/batch.
\end{abstract}

Kata kunci: Lean Manufacturing, Theory of Constraints (TOC), Drum Buffer Rope (DBR), ConWIP. 


\section{A. Pendahuluan}

CV. BJT merupakan industri yang menghasilkan kain celup dan kain printing. Strategy manufacturing yang diterapkan dalam menanggapi permintaan konsumen yaitu hybrid antara Make to Order (MTO) dan Make to Stock (MTS). Kain celup dengan warna dasar seperti merah, hitam, biru, dan putih merupakan kain yang dihasilkan untuk strategy MTS, sedangkan kain yang dihasilkan pada strategy MTO yaitu seluruh jenis kain yang menyesuaikan dengan pesanan konsumen.

Kegiatan produksi di CV. BJT disesuaikan dengan target yang sebelumnya telah direncanakan. Target produksi disusun berdasarkan 20\% untuk memenuhi kebutuhan MTS dan $80 \%$ untuk kebutuhan MTO. Salah satu aspek yang dipertimbangkan dalam merencanakan target produksi yaitu kapasitas yang tersedia pada sistem. Walaupun demikian, pada nyatanya CV. BJT selalu mengalami kekurangan dalam pemenuhan target produksi. Berdasarkan hasil studi dokumen dengan bagian PPIC, diketahui bahwa rata-rata kekurangan produksi pada tahun 2019 yakni sebesar 323.333 yard/bulan. Salah satu faktor penyebabnya yaitu ketidakseimbangan aliran produksi. Hal tersebut terjadi karena kapasitas yang dialokasikan tidak dijadwalkan serta dikelola dengan baik dan benar, sehingga menimbulkan penumpukan Work in Process (WIP) dan kegiatan waiting di beberapa stasiun kerja. Menurut Chiarini (2013) penumpukan WIP dan kegiatan waiting merupakan bagian dari jenis pemborosan (waste).

Dalam menjalankan kegiatan produksi, CV. BJT sudah menetapkan standar atau batas wajar adanya WIP pada setiap mesin yaitu sebesar 30\% dari WIP keseluruhan. Namun, kenyataanya masih ditemukan penumpukan WIP yang melebihi standar yaitu pada stasiun kerja Stenter sebesar 33,33\%, sebagaimana ditunjukan pada Tabel 1. Salah satu penyebabnya yaitu capacity constraints.

Tabel 1. Work In Process (WIP) antar stasiun kerja pada bulan Januari-Desember 2019

\begin{tabular}{|c|c|c|c|c|c|c|}
\hline No & $\begin{array}{l}\text { Departemen } \\
\text { Kerja }\end{array}$ & Stasiun Kerja & $\begin{array}{c}\text { Jumlah } \\
\text { Mesin }\end{array}$ & $\begin{array}{c}\text { Rata-rata } \\
\text { WIP } \\
\text { (batch/ } \\
\text { siklus) }\end{array}$ & $\begin{array}{c}\text { Rata-rata } \\
\text { WIP (batch/ } \\
\text { siklus/ } \\
\text { mesin) }\end{array}$ & $\begin{array}{c}\text { Persentase } \\
\text { WIP } \\
(\% / \text { mesin })\end{array}$ \\
\hline 1 & \multirow{4}{*}{$\begin{array}{c}\text { Persiapan } \\
\text { Penyempurnaan }\end{array}$} & Pile Up Kain & 1 & 0 & 0 & 0 \\
\hline 2 & & Kodefikasi & 1 & 3 & 3 & 20 \\
\hline 3 & & Sewing & 2 & 1 & 1 & 6,67 \\
\hline 4 & & $\begin{array}{l}\text { Relaxing dan } \\
\text { Scouring }\end{array}$ & 2 & 2 & 1 & 6,67 \\
\hline 5 & \multirow{2}{*}{ Dyeing } & Dyeing & 8 & 8 & 1 & 6,67 \\
\hline 6 & & Scutcher & 2 & 0 & 0 & 0 \\
\hline 7 & \multirow{3}{*}{ Printing } & Printing & 1 & 0 & 0 & 0 \\
\hline 8 & & Steaming & 3 & 9 & 3 & 20 \\
\hline 9 & & Washing & 1 & 0 & 0 & 0 \\
\hline 10 & \multirow[b]{2}{*}{ Finishing } & Stenter & 2 & 9 & 5 & 33,33 \\
\hline 11 & & $\begin{array}{l}\text { Pemotongan } \\
\text { Pinggir Kain }\end{array}$ & 2 & 0 & 0 & 0 \\
\hline 12 & \multirow{3}{*}{ Packaging } & Final Inspeksi & 10 & 5 & 1 & 6,67 \\
\hline 13 & & Rolling Dob Fold & 13 & 1 & 0 & 0 \\
\hline 14 & & Packing Kain & 13 & 0 & 0 & 0 \\
\hline \multicolumn{5}{|c|}{ Jumlah WIP } & 15 & $100 \%$ \\
\hline
\end{tabular}

Sumber data: CV. BJT, 2019

Dampak adanya penumpukan WIP di stasiun kerja Stenter menyebabkan kualitas kain yang menunggu untuk diproses menurun. Salah satu contoh penurunan kualitasnya yaitu watermark pada permukaan kain. Hal tersebut terjadi karena adanya reaksi obat kimia dengan air, kain, dan udara dalam durasi waktu lebih dari 15 menit, sehingga kain dengan kualitas yang tidak sesuai harus diproses ulang (rework) pada stasiun kerja Dyeing. Adanya permasalahan tersebut menyebabkan tingkat produktivitas CV. BJT menurun, sehingga output yang dihasilkan tidak sesuai dengan target produksi. Ketika target produksi tidak mampu terpenuhi, maka menyebabkan perusahaan kehilangan kesempatan untuk memperoleh throughput yang maksimum. Oleh karena itu, CV. BJT harus mampu mengendalikan, menjadwalkan, dan 
meningkatkan kapasitas yang tersedia dengan baik dan benar.

Berdasarkan latar belakang yang telah diuraikan, maka perumusan masalah dalam penelitian ini yaitu: "Apa saja penyebab adanya waste dan constraints pada saat proses produksi kain?", "Bagaimana cara untuk menyeimbangkan aliran produksi agar tidak menimbulkan waste dan mengelola constraints agar dapat meningkatkan throughput?", dan "Berapa jumlah WIP maksimum yang diperbolehkan ada pada setiap stasiun kerja, agar dapat mencapai throughput yang diinginkan?". Selanjutnya, tujuan yang ingin dicapai dalam penelitian ini sebagai berikut:

1. Mengidentifikasi penyebab munculnya waste dan constraints pada saat proses produksi kain.

2. Memberikan usulan perbaikan pada aliran produksi sebagai upaya untuk mengeliminasi kegiatan yang tidak memberikan nilai tambah serta mengelola constraints agar mencapai throughput maksimum.

3. Menetapkan standar WIP maksimum yang diperbolehkan ada pada setiap stasiun kerja guna mencapai throughput yang diinginkan.

Untuk mengatasi permasalahan di lantai produksi CV. BJT digunakan pendekatan Lean Manufacturing dan TOC secara bersamaan. Hal tersebut dikarenakan Lean Manufacturing dapat digunakan untuk mengatasi masalah pemborosan (waste) yang mempengaruhi kapasitas. Adapun TOC digunakan sebagai upaya untuk menyeimbangkan aliran produksi dengan memaksimalkan dan memanfaatkan constraints. Penerapan Lean Manufacturing dan TOC secara bersamaan telah dilakukan oleh beberapa peneliti, antara lain Dettmer (2001) dengan tujuan untuk meningkatkan performansi; Alvarez, Reyes, dan Aldas (2017) dengan tujuan untuk mengurangi waktu pengiriman dan reduksi inventory; dan Pacheco, dkk (2018) dengan tujuan untuk mengetahui kekuatan, kelemahan, dan kesenjangan dalam mengintegrasikan pendekatan konsep Theory of Constraints dan Lean Manufacturing.

\section{B. Metodologi}

Lean manufacturing dan TOC merupakan konsep yang digunakan untuk memperbaiki permasalahan secara sistem. Kedua konsep tersebut memiliki fokus pelanggan sebagai acuan yang digunakan dalam perbaikan secara terus menerus (Dettmer, 2001). Terdapat langkah utama yang harus dilakukan untuk mengintegrasikan kedua konsep yaitu harus mengadopsi perspektif Throughput, menentukan batas-batas sistem yang akan ditingkatkan, menentukan tujuan, dan menganalisis bagaimana tujuan itu dapat diukur dengan melakukan pengurangan biaya dan inventory (Dettmer, 2001). TOC dapat berfungsi sebagai mekanisme yang sangat efektif untuk memprioritaskan proyek perbaikan, sementara Lean Manufacturing dapat menyediakan berbagai alat dan teknik perbaikan, sebagaimana digambarkan pada Gambar 1 (Itasca, 2019).

Konsep dasar lean yaitu pendekatan keseluruhan sistem yang berfokus pada identifikasi dan eliminasi aktivitas yang tidak memiliki nilai tambah dalam suatu aliran (Sproull, 2019). Hal tersebut dilakukan agar tujuan untuk mengahasilkan produk dengan zero defect production, $100 \%$ Value added, pelanggan yang menarik kegiatan produksi (pull system). Aktivitas dalam proses produksi menurut Hines dan Taylor (2000) terbagi menjadi tiga bagian, yaitu Value adding activity (VA), Non-value adding activity (NVA), dan Necessary non-value adding activity (NNVA). Aktivitas NVA dan NNVA merupakan pemborosan (waste), karena tidak memberikan nilai tambah pada produk. Sebagaimana Chiarini (2013) menyatakan bahwa terdapat tujuh jenis pemborosan yang dapat diklasifikasikan, yaitu Overproduction, Waiting, Transportation, Overprocessing, Inventory, Motion, Defectiveness. 


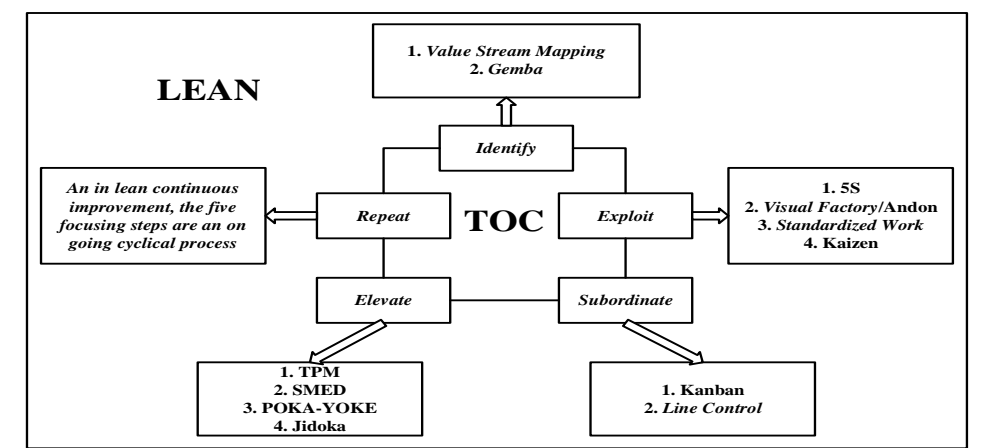

Gambar 1. Diagram Tahapan TOC dengan memanfaatkan alat Lean Manufacturing sebagai upaya perbaikan

Sementara itu, filosofi sistem manajemen yang mampu mengupayakan perbaikan secara terus-menerus pada constraints untuk mencapai tujuan perusahaan yaitu TOC (Tersine, 1994). TOC juga dapat meningkatkan throughput dan kapasitas yang menjadi kendala pada sistem dengan cara mengelola dan menjadwalkan kendala tersebut. Menurut Techt (2015) TOC memiliki tiga indikator kinerja utama atau Key Performance Indicators (KPI) dasar yang dapat digunakan untuk menilai suatu keputusan yaitu throughput, inventory, dan Operating Expense. Umble dan Srikant (1996) menjelaskan terdapat beberapa jenis constraints yang sering ditemukan pada sistem yaitu market constraints, material constraints, capacity constraints, logistical constraints, dan managerial constraints.

Cox dan Schleier (2010) menjelaskan bahwa mekanisme penjadwalan dan kontrol yang yang dapat digunakan untuk mengimplementasikan TOC di lantai produksi yaitu Drum Buffer Rope (DBR). Proses pengaturan drum dimulai dengan mengidentifikasi pekerjaan yang perlu dilakukan pada constraints dengan total output yang dibutuhkan. Buffer adalah material hulu drum memastikan bahwa tidak pernah kosong. Tujuan dari buffer adalah melindungi throughput sistem dari kendala internal proses produksi. Rope adalah mekanisme pensinyalan dari buffer untuk menarik material ke hulu dengan kecepatan laju drum. Implementasi rope berupa Backward Scheduling. Penugasan pekerjaan berurutan mulai dari posisi terakhir dan melanjutkan mundur (backward) menuju posisi pertama. Keuntungan penjadwalan ini adalah dapat mengurangi WIP (Sule, 2008). Selain itu WIP perlu dikontrol dengan menggunakan ConWIP. Leonardo, dkk (2017) menyatakan bahwa sistem ConWIP dapat mengendalikan pabrik pada tingkat pekerjaan yang konstan di proses meskipun tidak berusaha untuk mengontrol lokasi WIP dalam sistem.

\section{Hasil dan Pembahasan}

Upaya perbaikan pada penelitian ini dilakukan dengan cara menerapkan langkah-langkah TOC dan memanfaatkan tools Lean Manufacturing yang dapat dilihat pada uraian berikut:

\section{Identifikasi Constraints dengan tools Value Stream Mapping (VSM).}

Seperti yang sudah diketahui bahwa terdapat penumpukan WIP yang melebihi standar perusahaan yaitu pada stasiun kerja Stenter sebesar 33,33\%. Salah satu penyebabnya karena kapasitas yang tersedia sebesar 61.560 menit/bulan, sedangkan kapasitas yang dibutuhkan sebesar 78.860,60 menit/bulan, sehingga memberikan arti bahwa stasiun kerja Stenter tidak mampu memenuhi kebutuhan atau constraints. Adanya penumpukan WIP dan waiting waste membuat production lead time current state menjadi panjang yaitu sebesar 2.229,48 menit/batch, sebagaimana ditunjukan pada Gambar 2. Dimana production lead time terdiri dari waktu kegiatan VA, NVA, dan NNVA, sebagaimana dapat dilihat pada Tabel 2.

Besar kecilnya waktu yang digunakan oleh kegiatan NNVA dan NVA akan mempengaruhi terhadap persentase Process Cycle Efficiency (PCE). Adapun persentase PCE current state di lantai produksi CV. BJT yaitu: $\mathrm{PCE}=\frac{1.483,94 \text { menit } / \text { batch }}{2.229,48 \text { menit } / \text { batch }} \times 100 \%=66,56 \%$. Berdasarkan hasil tersebut, diketahui bahwa terdapat $33,44 \%$ waktu yang digunakan di lantai produksi ialah untuk kegiatan yang tidak memberikan nilai tambah atau waste, sehingga masih ada peluang untuk 
meningkatkan efficiency system agar mendekati $100 \%$ dengan menerapkan kaizen atau continues improvement.

Tabel 2. Rekapitulasi waktu setiap kategori aktivitas

\begin{tabular}{|c|l|c|c|}
\hline No & \multicolumn{1}{|c|}{ Kategori Kegiatan } & Total waktu (menit/batch) & Persentase waktu (\%) \\
\hline 1 & Value adding activity & $1.483,94$ & 67 \\
\hline 2 & Non-value adding activity & 406,51 & 15 \\
\hline 3 & $\begin{array}{l}\text { Necessary non-value adding } \\
\text { activity }\end{array}$ & 339,03 & 18 \\
\hline \multicolumn{2}{|l}{ Production lead time } & $\mathbf{2 . 2 2 9 , 4 8}$ & \\
\hline
\end{tabular}

Sumber: Data Penelitian yang Sudah Diolah, 2021

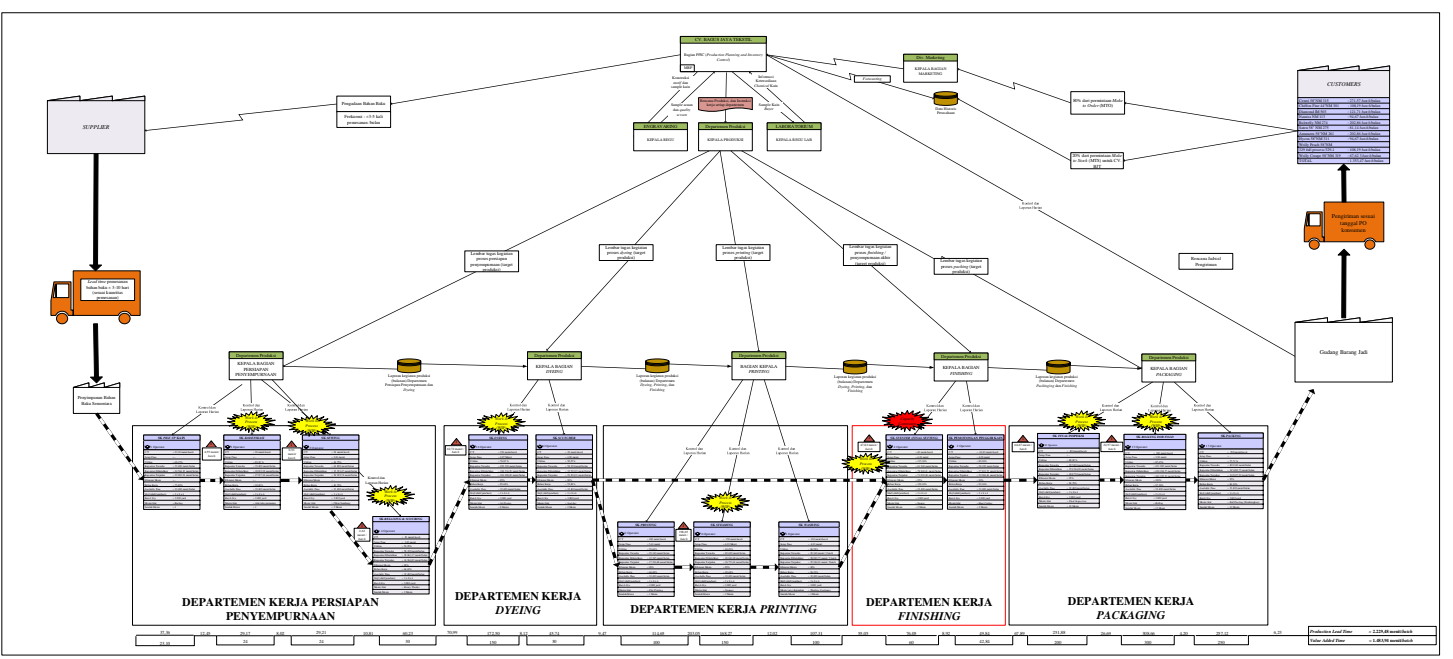

Gambar 2. Value Stream Map (Current State)

Setelah VSM current dirancang, langkah selanjutnya yaitu identifikasi secara detail jenis waste yang ada pada VSM. Langkah ini dilakukan untuk mengetahui apakah terdapat kendala lain selain capacity constraints yang mempengaruhi CV. BJT dalam mencapai memenuhi target produksi. Identifikasi waste dilakukan menggunakan kuesinoer 7 waste, Value Stream Analysis Tools (VALSAT), dan detailed mapping. Berdasarkan hasil pembobotan kuesioner 7 waste, diketahui bahwa persentase untuk jenis waste over production 3\%, defect 19\%, inventory 29\%, Excess Processing 8\%, transportation 5\%, waiting 26\%, dan unnecessary motion $10 \%$. Selanjutnya dilakukan upaya perbaikan pada jenis waste dengan score tertinggi dan berpengaruh terhadap tujuan perusahaan yaitu inventory dan waiting. Hasil dari pembobotan waste akan digunakan sebagai input pada VALSAT guna memilih dan mengetahui tools yang sesuai dengan jenis waste di lantai produksi CV. BJT.

Hasil matriks VALSAT menunjukkan bahwa score mapping tools tertinggi yaitu Process Activity Mapping (PAM) dengan score 338. Terpilihnya tools PAM memberi arti bahwa waste yang teridentifikasi pada VSM memiliki kaitan dengan kegiatan proses produksi kain. Tools yang terpilih berdasarkan VALSAT akan digunakan pada tahapan detailed mapping dan analisa perbaikan waste. Tabel 3 merupakan rekapitulasi pengelompokan kegiatan PAM (Current state). Berdasarkan Tabel 3, diketahui bahwa terdapat aktivitas yang tidak memberikan nilai tambah sebesar 33,44\%. Delay/waiting merupakan penyumbang terbesar yaitu $18 \%$ total production lead time. Oleh karena itu, kegiatan tersebut harus segera direduksi agar tidak merugikan perusahaan. Setelah waste diketahui, langkah selanjutnya yaitu mengidentifkasi akar penyebab timbulnya waste di lantai produksi. Identifikasi penyebab timbulnya waste dilakukan dengan menggunakan fishbone diagram, sebagaimana ditunjukan pada Gambar 3.

Waste yang akan direduksi, dipilih berdasarkan score tertinggi pada tahap pembobotan waste dan kegiatan NVA pada detailed mapping. Output dari kedua tahap tersebut memiliki keterkaitan, kegiatan NVA pada detailed mapping yaitu delay/waiting, dimana penyebabnya karena ada penumpukan inventory berupa WIP. Sementara itu, waste yang memiliki score tertinggi pada tahap pembobotan waste yaitu inventory, sehingga waste yang akan direduksi dipertimbangkan 
dari kedua tahapan tersebut. Adapun faktor penyebab timbulnya waste tersebut dapat dilihat pada Gambar 3.

Tabel 3. Ringkasan Pengelompokan Kegiatan PAM (Current state)

\begin{tabular}{|c|c|c|c|c|c|}
\hline \multirow{2}{*}{ Aktifitas } & \multirow{2}{*}{$\begin{array}{c}\text { Jumlah } \\
\text { kegiatan }\end{array}$} & \multirow{2}{*}{ Persentase } & $\begin{array}{c}\text { Aalue } \\
\text { adding } \\
\text { activity }\end{array}$ & $\begin{array}{c}\text { Non-value } \\
\text { adding } \\
\text { activity }\end{array}$ & $\begin{array}{c}\text { Necessary } \\
\text { non-value } \\
\text { adding activity }\end{array}$ \\
\hline Operation & 45 & $65 \%$ & $1.283,94$ & - & 162,54 \\
\hline Inspection & 2 & $9 \%$ & 200 & - & 8,34 \\
\hline Storage & 12 & $3 \%$ & - & - & 60,23 \\
\hline Transportation & 15 & $5 \%$ & - & - & 107,92 \\
\hline Delay & 8 & $18 \%$ & - & 406,51 & - \\
\hline \multicolumn{2}{|l|}{ Total } & $\mathbf{8 2}$ & $\mathbf{1 0 0 \%}$ & & \multicolumn{2}{|c|}{$\mathbf{2 . 2 2 9 , 4 8}$} \\
\hline
\end{tabular}

Sumber: Data Penelitian yang Sudah Diolah, 2021

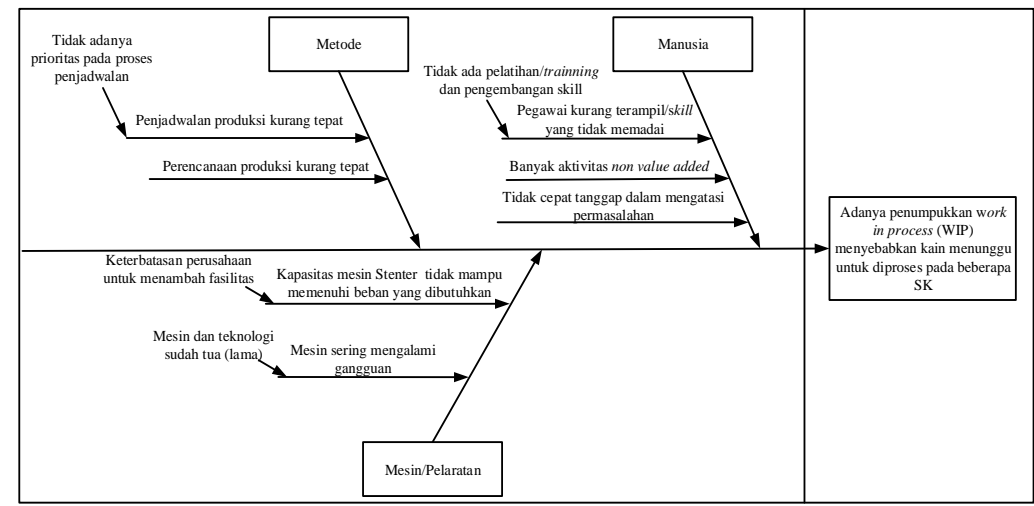

Gambar 3. Fishbone Diagram timbulnya waste WIP yang menyebabkan kain menunggu untuk diproses pada beberapa stasiun kerja

Setelah constraints dan waste teridentifikasi, langkah selanjutnya yaitu menerapkan eksploitasi untuk mengendalikan stasiun kerja constraints yang menyebabkan timbulnya inventory dan waiting waste. Salah satu upaya yang dilakukan untuk mereduksi kedua jenis waste yaitu dengan menyeimbangkan lintasan produksi, agar aliran material dan informasi antar sumber daya sinkron. Jika lintasan produksi pada sebuah pabrik seimbang, maka akan mempersingkat production lead time, dan meningkatkan produktivitas (hasil produksi).

\section{Eksploitasi Constraints dengan DBR dan Logical Approach Synchronous Manufacturing}

Drum merupakan constraints, dimana digunakan sebagai titik pengendali untuk memastikan bahwa stasiun kerja upstream memproduksi sesuai dengan kebutuhan constraints, sehingga tidak menimbulkan WIP dan utilitas constraints $100 \%$. Upaya yang dilakukan agar tingkat utilitas stasiun kerja Stenter $100 \%$ yaitu dengan memaksimalkan kapasitas melalui variabel hari kerja dan peningkatan efisiensi mesin, sebagaimana ditunjukan pada Tabel 4. Berdasarkan hasil peningkatan kapasitas tersedia pada stasiun kerja Stenter, diketahui bahwa kapasitas tersedia kondisi future sebesar 79.027,20 menit/bulan. Sementara itu, kapasitas yang dibutuhkan pada stasiun kerja Stenter untuk memenuhi target produksi agar mencapai throughput maksimum sebesar 78.860,61 menit/bulan, sehingga kondisi future stasiun kerja Stenter mampu memenuhi target produksi. Selain itu, terdapat kelebihan kapasitas sebesar 166,59 menit/bulan yang mana dapat dialokasikan sebagai allowance bagi operator selama satu bulan atau dimanfaatkan untuk memenuhi permintaan kain, jika sewaktu-waktu CV. BJT mengalami peningkatan permintaan.

Setelah stasiun kerja constraints ditingkatkan, maka selanjutnya yaitu menentukan tingkat produksi yang akan memaksimumkan throughput dengan menggunakan Logical Approach Synchronous Manufacturing. Berdasarkan hasil perhitungan, diketahui bahwa throughput yang diperoleh oleh CV. BJT pada kondisi future menjadi meningkat dari Rp. 9.255.067.125 menjadi 
Rp.10.297.640.532. Hal tersebut dapat terjadi karena aliran produksi di CV. BJT sudah diseimbangkan dengan upaya memaksimalkan kapasitas tersedia stasiun kerja Stenter. Setelah drum diketahui dan kapasitas stasiun kerja Stenter ditingkatkan, langkah selanjutnya yaitu menentukan rope. Implementasi rope dilakukan berdasarkan titik kendali (control point) yang diperintahkan oleh stasiun kerja Stenter ke Pile Up Kain (non constraints). Implementasi rope dilakukan pada tahapan ketiga TOC yaitu subordinasi non constraints.

Tabel 4. Simulasi dalam memaksimalkan kapasitas stasiun kerja Stenter

\begin{tabular}{|c|c|c|c|}
\cline { 2 - 3 } \multicolumn{1}{c|}{} & Current & Future & \multicolumn{1}{c|}{} \\
\hline Jam Kerja Efektif & 7,50 & 8 & jam/shift \\
\hline shift & 3 & 3 & shift/hari \\
\hline Hari Kerja & 6 & 7 & hari/minggu \\
\hline Jumlah kerja Bulan & 24 & 28 & hari/bulan \\
\hline Total Availabity & 540 & 672 & Jam/bulan \\
\hline Efficiency Machine & 95 & 98 & $\%$ \\
\hline Jumlah Mesin & 2 & 2 & mesin \\
\hline Kapasitas Tersedia & $\mathbf{6 1 . 5 6 0}$ & $\mathbf{7 9 . 0 2 7 , 2 0}$ & menit/bulan \\
\hline Kebutuhan Kapasitas & \multicolumn{2}{|c|}{$\mathbf{7 8 . 8 6 0 , 6 1}$} & menit/bulan \\
\hline Gap kapasitas & $\mathbf{- 1 7 . 3 0 0 , 6 1}$ & $\mathbf{1 6 6 , 5 9}$ & menit/bulan \\
\hline
\end{tabular}

Sumber: Data Penelitian yang Sudah Diolah, 2021

\section{Subordinasi Non-Constraints dengan ConWIP dan Penjadwalan Backward}

Subordinasi non constraints dilakukan berdasarkan hasil implementasi dari eksploitasi terhadap kapasitas yang dimiliki oleh stasiun kerja constraints. Demi menjaga tingkat utilitas stasiun kerja constraints $100 \%$ dan memastikan stasiun kerja non-constraints telah memenuhi kebutuhan secara tepat waktu, perlu adanya penerapan sistem ConWIP dan penjadwalan flow shop pada stasiun kerja upstream dengan algoritma Campbell Dudek and Smith (CDS) dan pendekatan backward.

Langkah awal perbaikan pada tahap subordinasi non constraints yaitu dengan menerapkan sistem ConWIP dengan tujuan untuk mengontrol, mengendalikan dan mengurangi tingkat WIP agar CV. BJT dapat mencapai throughput yang diinginkan. Guna mengetahui jumlah maksimum WIP yang boleh tersebar di jalur ConWIP agar throughput yang diperoleh maksimum dapat dilihat sebagai berikut.

Level WIP kritis $\left(\mathrm{W}_{0}\right)=\sum \mathrm{T}_{0} \times r_{b}$ minimum

Level WIP kritis $\left(\mathrm{W}_{0}\right)=616,99$ menit $\mathrm{x} 0,035 \mathrm{batch} / \mathrm{menit}$

Level WIP kritis $\left(\mathrm{W}_{0}\right)=21,85 \approx 22$ batch

Dimana, $\mathrm{T}_{0}$ merupakan rata-rata waktu proses pada stasiun kerja, sedangkan $r_{b}$ merupakan kapasitas paling kritis di jalur ConWIP. Berdasarkan hasil perhitungan, diketahui bahwa jumlah maksimum WIP yaitu sebesar 22 batch. Setelah mengetahui jumlah maksimum WIP yang boleh ada di jalur ConWIP, maka selanjutnya yaitu mengendalikan dan mengontrol agar aliran produksi seimbang (tidak menimbulkan waste). Salah satu upaya yang dilakukan yaitu dengan memberlakukan sistem berbasis kartu ConWIP. Adapun perhitungan jumlah kartu ConWIP sebagai berikut:

$$
\begin{array}{lcc}
\text { TH }(w) & =\frac{w}{w+W 0-1} \mathrm{r}_{\mathrm{b}} \\
0,018 & =\frac{w \times(0,035)}{w+21,85-1} \\
0,018 & =\frac{w \times(0,035)}{w+20,85} \\
0,018+0,365 & =w \times 0,035 \\
1 w \quad=0,49 w+10,42 \\
0,51 w & =10,42 \\
w & =\frac{10,42}{0,51} \\
w & =20,43 \approx 20 \text { kartu ConWIP }
\end{array}
$$


Berdasarkan hasil perhitungan, jumlah kartu ConWIP yang akan digunakan untuk mengendalikan aliran produksi di CV. BJT yaitu sebanyak 20 kartu. Banyaknya jumlah kartu berkaitan juga dengan banyaknya pekerjaan yang sedang berlangsung di jalur ConWIP, dimana 1 kartu mewakili 1 batch. Sementara itu, untuk mengetahui WIP maksimum pada setiap stasiun kerja dapat dilihat sebegai berikut:
WIP Stasiun kerja Stenter
$=\mathrm{TH} \times \mathrm{CT}$
WIP Stasiun kerja Stenter
$=0,035 \mathrm{batch} / \mathrm{menit} \times 56,46$ menit
WIP Stasiun kerja Stenter
$=2$ batch

Perhitungan jumlah maksimum WIP yang diperbolehkan pada setiap stasiun kerja dipengaruhi oleh 2 faktor yaitu throughput atau the bottleneck rate paling kritis, dan cycle time (CT) atau nilai $\mathrm{T}_{0}$. Dimana pada penelitian ini the bottleneck rate paling kritis yaitu stasiun kerja Stenter sebesar 0,035 batch/menit. Adapun rekapitulasi perhitungan standar atau batas limit WIP dapat dilihat pada Tabel 5.

Tabel 5. Rekapitulasi perhitungan standard atau batas limit WIP

\begin{tabular}{|c|c|c|c|c|}
\hline Stasiun Kerja & $\begin{array}{c}\text { Jumlah } \\
\text { Mesin }\end{array}$ & $\begin{array}{l}\text { Raw Processing } \\
\text { Time (menit/ } \\
\text { batch) }\end{array}$ & $\begin{array}{c}\text { The Bottleneck } \\
\text { Rate (batch/menit) }\end{array}$ & $\begin{array}{c}\text { WIP } \\
\text { (batch/siklus) }\end{array}$ \\
\hline Pile Up Kain & 1 & 17,41 & 0,06 & $0,62 \approx 1$ \\
\hline Kodefikasi & 1 & 21,34 & 0,05 & $0,76 \approx 1$ \\
\hline Sewing & 2 & 23,37 & 0,09 & $0,83 \approx 1$ \\
\hline Relaxing dan Scouring & 2 & 28,04 & 0,07 & $0,99 \approx 1$ \\
\hline Dyeing & 8 & 137,17 & 0,06 & $4,86 \approx 4$ \\
\hline Scutcher & 2 & 23,79 & 0,08 & $0,84 \approx 1$ \\
\hline Printing & 1 & 72,19 & 0,07 & $2,56 \approx 3$ \\
\hline Steaming & 3 & 140,94 & 0,10 & $4,99 \approx 5$ \\
\hline Washing & 1 & 96,26 & 0,05 & $3,41 \approx 3$ \\
\hline Stenter & 2 & 56,46 & 0,035 & 2 \\
\hline Total & & 616,99 & & $21,85 \approx 22$ \\
\hline
\end{tabular}

Sumber: Data Penelitian yang Sudah Diolah, 2021

Usulan perbaikan dengan menerapkan sistem ConWIP pada lini produksi sebelum stasiun kerja constraints dapat mereduksi WIP sebesar 31,25\% dibandingakan kondisi awal. Selain itu, dengan menerapkan sistem ConWIP mampu mereduksi waktu tunggu WIP pada stasiun kerja Stenter dari kondisi awal 53,74 menjadi 11,94 menit/batch. Berkurangnya waktu tunggu WIP berdampak positif pada eliminasi defect waste yang diakibatkan kain mengantri untuk diproses pada stasiun kerja Stenter dalam durasi lebih dari 15 menit. Adapun Skema Lini Produksi pada jalur ConWIP dapat dilihat pada Gambar 4.

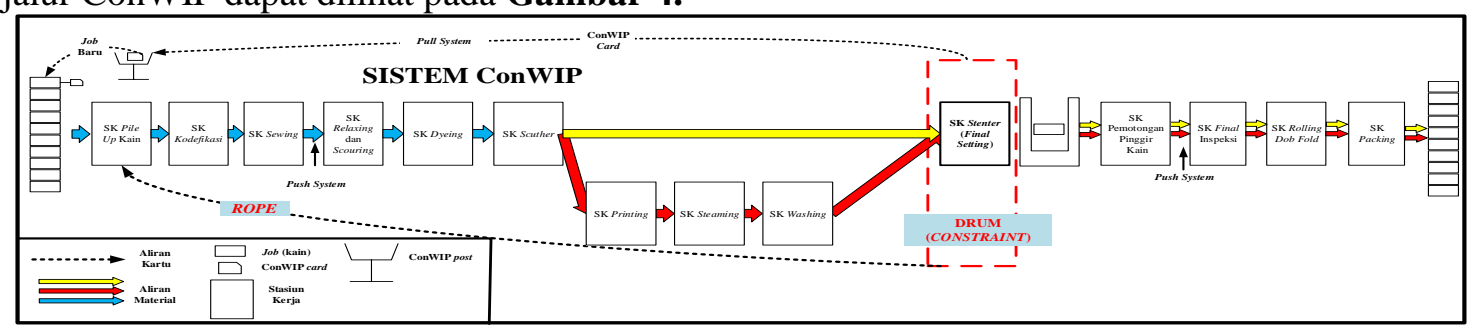

Gambar 4. Skema Lini Produksi pada jalur ConWIP

Setelah standar maksimum WIP pada setiap stasiun kerja diberlakukan, langkah selanjutnya yaitu menjadwalkan kebutuhan stasiun kerja Stenter dari stasiun kerja Pile up Kain. Pendekatan penjadwalan yang digunakan yaitu backward scheduling. Penjadwalan tersebut diterapkan guna mengatahui kapan waktu yang tepat untuk mulai mengerjakan suatu pesanan agar dapat diselesaikan sesuai due date pada stasiun kerja Stenter, sehingga apabila pengerjaan job dari stasiun kerja Pile Up Kain sampai dengan stasiun kerja Stenter tidak sesuai dengan due date, maka target produksi tidak tercapai. Oleh karena itu, pendekatan backward diadopsi untuk membuat due date pengerjaan job. 
Selain itu, dilakukan penentuan urutan job yang akan diproduksi terlebih dahulu atau sequencing. Salah satu cara yang digunakan untuk menentukan urutan job dengan mencari nilai makespan terkecil yaitu menggunakan algoritma CDS. Tujuan yang ingin dicapai dari penjadwalan ini adalah minimasi WIP dengan cara reduksi mean flow time, dan memenuhi target produksi dengan mencari nilai makespan terkecil. Adapun rekapitulasi mengenai total makespan dari setiap alternatif penjadwalan dapat dilihat pada Tabel 6.

Tabel 6. Rekapitulasi Makespan

\begin{tabular}{|c|c|}
\hline Alternatif K (Iterasi) & Makespan (menit/bulan) \\
\hline 1 & $67.071,15$ \\
\hline 2 & $64.839,43$ \\
\hline 3 & $65.117,85$ \\
\hline 4 & $66.341,17$ \\
\hline 5 & $67.403,03$ \\
\hline 6 & $66.062,75$ \\
\hline 7 & $64.839,43$ \\
\hline 8 & $64.839,43$ \\
\hline 9 & $65.117,85$ \\
\hline
\end{tabular}

Berdasarkan penjadwalan dari iterasi ke-1 sampai dengan iterasi ke-9 diketahui bahwa terdapat 3 alternatif penjadwalan terbaik yaitu iterasi ke-2, ke-7, dan ke-8. Waktu yang diperlukan untuk menyelesaikan keseluruhan job (makespan) pada alternatif tersebut yaitu 64.839,43 menit/bulan, dengan sequence Ceruti - Amunzen - Balotelly - Diamond IM - Wolly Peach Chiffon Fine - Hycon - Mosscrape - Wolly Crepe - Saten. Urutan awal job yang akan diproduksi pada stasiun kerja Stenter berdasarkan iterasi terpilih yaitu kain Ceruti, sehingga kain yang diproses setelah stasiun kerja Stenter akan mengikuti berdasarkan urutan sequence tersebut. Sementara itu, untuk mengetahui waktu yang dibutuhkan setiap jenis kain (based on production targets) dari stasiun kerja Pile Up Kain sampai dengan Stenter dapat dilihat pada Tabel 7.

Tabel 7. Rekapitulasi total waktu yang dibutuhkan setiap job (base on due date Stenter)

\begin{tabular}{|c|c|c|c|c|}
\hline \multirow{2}{*}{ No } & \multirow{2}{*}{ Job } & \multirow{2}{*}{$\begin{array}{c}\text { Waktu yang } \\
\text { dibutuhkan } \\
\text { (menit/bulan) }\end{array}$} & \begin{tabular}{c} 
Starting Time (bi) \\
\cline { 3 - 5 }
\end{tabular} & $\begin{array}{c}\text { Completion Time } \\
\text { (Ci) }\end{array}$ \\
\hline 1 & Ceruti & $43.476,35$ & 0 & $\begin{array}{c}\text { Stenter } \\
\text { Stan }\end{array}$ \\
\hline 2 & Amunzen & $41.033,94$ & $8.147,17$ & $43.476,35$ \\
\hline 3 & Balotelly & $39.199,91$ & $14.398,74$ & $53.181,10$ \\
\hline 4 & Diamond IM & $35.379,23$ & $20.150,76$ & $55.598,65$ \\
\hline 5 & Wolly Peach & $33.614,44$ & $23.616,56$ & $57.231,00$ \\
\hline 6 & Chiffon Fine & $32.330,57$ & $26.566,47$ & $58.897,03$ \\
\hline 7 & Hycon & $30.770,57$ & $29.635,50$ & $60.406,07$ \\
\hline 8 & Mosscrape & $29.746,34$ & $32.221,23$ & $61.967,57$ \\
\hline 9 & Wolly Crepe & $28.507,30$ & $35.062,15$ & $63.569,44$ \\
\hline 10 & Saten & $27.848,30$ & $36.991,13$ & $64.839,43$ \\
\hline
\end{tabular}

Ketika upaya perbaikan sudah diterapkan secara keseluruhan, maka production lead time akan berkurang dari kondisi awal sebesar 2.229,48 menjadi 2.005,62 menit/batch. Sejalan dengan itu, ketika production lead time berkurang dan value added time tetap sama, maka akan meningkatkan persentase PCE dari kondisi awal sebesar 66,56\% menjadi 73,99\%.

\section{Kesimpulan}

Kesimpulan yang didapatkan dari hasil penelitian ini yaitu:

1. Penyebab munculnya waste dan constraints memiliki keterkaitan, dimana faktor tersebut terdiri dari manusia/operator, metode, dan mesin/peralatan. Operator banyak melakukan kegiatan NVA dan operator tidak memanfaatkan kapasitas secara baik dan benar, sehingga mempengaruhi output yang dihasilkan. Pada faktor metode, tidak ada aturan 
prioritas pada saat penjadwalan, sehingga menimbulkan permasalahan seperti stasiun kerja idle, dan WIP. Sementara pada faktor mesin/peralatan tidak dimanfaatkan dengan baik dan benar, sehingga menyebabkan permasalahan seperti timbulnya WIP, dan capacity constraints.

2. Upaya mengeliminasi waste dan mengendalikan constraints yaitu menggunakan sistem ConWIP dan memaksimalkan pemanfaatan stasiun kerja Stenter dengan menambah jam kerja serta meningkatkan efisien mesin Stenter menjadi 98\%, agar tidak menimbulkan WIP yang mengakibatkan target tidak terpenuhi. Berlakunya sistem ConWIP dapat mereduksi waktu tunggu dan WIP, sedangkan memaksimalkan kapasitas SK Stenter mampu mengendalikan constraints agar menghasilkan throughput maksimum.

3. Standar WIP pada setiap stasiun kerja dijalur ConWIP yaitu Pile Up Kain 1 batch/siklus, Kodefikasi 1 batch/siklus, Sewing 1 batch/siklus, Relaxing dan Scouring 1 batch/siklus, Dyeing 4 batch/siklus, Scutcher 1 batch/siklus, Printing 3 batch/siklus, Steaming 5 batch/siklus, Washing 3 batch/siklus, Stenter 2 batch/siklus. Penentuan standar WIP sudah dipengaruhi oleh stasiun kerja constraints dan target produksi.

\section{Acknowledge}

Terima kasih kepada seluruh pihak yang telah memberikan ilmu, dukungan, dan doa kepada penulis, sehingga penelitian ini dapat terlaksana dan diselesaikan dengan baik.

\section{Daftar Pustaka}

[1] Alvarez, K., Aldas, D., dan Reyes, J., 2017. Towards Lean Manufacturing from Theory of Constraints: A Case Study in Footwear Industry, International Conference on Industrial Engineering, Management Science and Application (ICIMSA), [e-journal], pp 1-8. Tersedia pada: ResearchGate <http://doi: 10.1109/ICIMSA.2017.7985615> [Diakses 12 Agustus 2020].

[2] Chiarini, A., 2013. Lean Organization: from the tools of the Toyota Production System to Lean Offiice. Bologna: Spinger.

[3] Cox III, J. F., dan Schleier Jr, J. G. (eds)., 2010. Theory Of Constraints Handbook. New York: The McGraw-Hill Companies, Inc.

[4] Dettmer, H. W., 2001. Beyond Lean Manufacturing: Combining Lean and the Theory of Constraints for Higher Performance. Los Anggeles: Port Angeles.

[5] Hines, P., dan Taylor, D., 2000. Going Lean, Lean Enterprise Research Center. Cardiff: Business School.

[6] Itasca, IL., 2019. Combining Theory of Constraints and Lean Manufacturing. [online] Illinois: Vorne Industries Inc. Tersedia pada: < https://www.leanproduction.com> [Diakses 12 November 2020].

[7] Leonardo, D. G., Sereno, B., Silva, D. S., dan Sampaio, M., 2017. Implementation of Hybrid Kanban-ConWip System: a Case Study. Journal of Manufacturing Technology Management, [e-journal] 28(6), pp 714-736. Tersedia pada: <https://doi.org/10.1108/JMTM-03-2016-0043> [Diakses 29 April 2020].

[8] Pacheco, D. A d.J., Pergher, I., Antunes Junior, J.A.V, dan Roehe Vaccaro, G.L., 2018. Exploring The Integration Between Lean and The Theory of Constraints in Operations Management, International Journal of Lean Six Sigma, [e-journal] 10(3), pp 718-742. Tersedia pada: Emerald insight <https://doi.org/10.1108/IJLSS-08-2017-0095> [Diakses 3 Maret 2020].

[9] Sproull, B., 2019. Theory of Constraints, Lean, and Six Sigma Improvement Methodology: Making the Case for Integration. New York: Productivity Press.

[10] Sule, D. R., 2008. Production Planning and Industrial Scheduling: Examples, Case Studies and Applications. Second Edition. Boca Raton: CRC Press

[11] Tersine, J. R., 1994. Principles of Inventory and Material Management. Fourth Edition. New Jersey: PTR Prentice Hall Inc.

[11] Techt, U., 2015. Goldratt and The Theory of Constraints: The Quantum Leap in 
Management. Stuttgart: Ibidem Press.

[12] Umble, M. M., dan Srikant, M. L., 1996. Synchronous Manufacturing-Principles for WorldClass Excellence. Wellington: The Spectrum Publishing Company. 